\title{
Predestinasi
}

Vol. 13, No. 2, Desember 2020, Hal. 107- 114

ISSN (Print): 1978-9351

\section{Repositioning Democratic Governance in Africa for Better Dividends Delivery: A Case for Performance}

\author{
Ephraim A. Ikegbu ${ }^{1}$, Godwin C.S.P. Iwuchukwu ${ }^{2}$, Peter B. Bisong ${ }^{3}$ \\ 1,3, Department of Philosophy \\ University of Calabar, Calabar, Cross River State, Nigeria. \\ *e-mail: a.eikegbu@unical.edu.ng ${ }^{1}$ \\ 2, Department of Linguistics \& Communications \\ University of Calabar, Calabar, Cross River State, Nigeria. \\ *e-mail: godwiniwuchukwu@gmail.com²
}

\begin{abstract}
Given the fact that democracy as a system and form of governance which allows for even participation, freedom of expression, rule of law and other indices attached thereto, had awaken the consciousness of humanity from all over the world to key into this form of leadership due to its uncommon benefits. Africa her 'third world cousins' seemed to have remained in a slumbering position and have refused to wake up and wear the toga of democratic principles as acts displayed by leaders lacked democratic character. This paper argues that democratic dividends and flavour can be felt and directly impacted on the citizens of Africa especially Nigeria, if adequate political socialization, culturalization and consciousness are fused as part of her cultural education. This new consciousness and democratic mindset will arguably make leaders and the led see each other as an inclusive indispensable part of the whole. It will also eliminate unwantom suspicion, rancour, ethnic bigotry, exclusion and hegemonic display of power and more so, leadership may not be tenured but anchored on performance and service delivery. The paper believes that with a political consciousness, socialization and high sense of political culture, leadership becomes service to the humanity and not business enterprise. Hence leaders that performed optimally may continue to serve the people if they so desire. This paper adopts critical, analytical and expository methods.
\end{abstract}

Keywords: Democracy; Poverty; Ignorance; Socialization; Culturalization.

\section{INTRODUCTION}

Failure to take into cognizance the fact that, not everything that works in the West and other developed countries will work in Africa, has been the mistake that Africa is slow in correcting. Ever since its displacement by colonialism, Africa has tended to sheepishly follow the West in almost all things, from religion, language, dressing, to dancing. Its educational curricula are purely western. Its economic system is western and more frustrating; its political system is tailored after the West.

Nigeria and most African countries are now democratic like the West. Democracy however, has failed to yield the expected dividends in the continent, making many to question the reasoning behind its enthronement (Ikegbu \& Enyimba 2010). The failure of democracy in 
the continent seems to lay credence to Elijah John (2009) assertion that "certain nations of the world are not ripe yet for democracy" (p. 68). We agree with John that most African nations are not yet ripe for democracy, though reservation as certain fragments of Africa such as South Africa, Ghana, Rwanda, Kenya even Gambia have some elements and features of democracy in their political system (Ikegbu et al., 2013).

Democracy does not thrive well in areas of mass illiteracy/ignorance, endemic poverty and tribalism. Democracy demands mass participation, and effective mass participation can only come when the citizens are politically enlightened, economically vibrant and detribalized. This paper argues that Africa can only reap the dividends of democracy, if the educational and poverty level in the continent are improved and communalistic spirit completely exorcised. Thus this where it happens will differentiate African democracy from western democracy that is tenure based and not performance. African democracy (Nigeria) for it to gain its desired flavour and acceptability status must be anchored on performance of the leaders. A leader who has performed optimally must be made to continue until he becomes weak and incapable of discharging his functions either on health ground or age or both.

\section{MEANING AND NATURE OF DEMOCRACY}

The origin of the term democracy is traceable to the 5th century BC, where it was used in Greek city-states, notably Athens (Wilson, 2006). It is derived from two Greek words demos (people) and kratos (rule). It therefore, etymologically means rule by the people. In consonance with this etymological meaning, Appadorai captures it as a "system of government under which the people exercise the governing power directly or through representative periodically elected by themselves" (p. 137). For Nnamdi Azikiwe (1974), it means "the rule of the people by its majority inhabitants and it includes a government in which the supreme power is vested in the people and exercised by them directly or indirectly through a system of representation, usually involving periodically held free and fair elections" (p. 2-3). John Dewey sees it as "the settling for free use of the experimental method in social inquiry and thought, which is required for the solution of concrete social, political and industrial problems" (Coppleston 1984, p. 373). According to Elijah John (2009), democracy is a "method of government through which leaders are held accountable for their actions and inactions in the public realm, and by which citizens are actively involved in the completion and cooperation of their elected representatives" (p. 68).

Though, democracy lacks a universally accepted definition, it could be said from the definitions above that democracy has identifiable marks, some of which include: existence of a constitution, Regular, free and fair elections: Existence of Federalism, an independent judiciary: Powers of the presidency, A free media: Transparency: Civilian control of the military, Multiparty system, Equality before the law, Political tolerance, Accountability: Human rights, Neutrality of state institutions, Rule of law. In our view, democracy implies no less than a civilianized system of leadership with inclusive character conferred on persons or group of persons in a representative flavour on trust, for the management and administration of the commonwealth of the people while ensuring equity, fair play, justice in resource allocation and distribution and freedom of opinion and association.

\section{THE CHALLENGES OF DEMOCRACY IN AFRICA}

The major challenges facing democracy in Nigeria are illiteracy/political ignorance, poverty and communal consciousness. 


\section{Illiteracy/political ignorance}

Arguably, more than one half of African population is believed to be illiterate. Inability to read and write robs most Africans of the opportunity to get abreast with the political happenings around them. Success of democracy largely depends on active participation of the citizens. Active participation however, depends on how politically informed the people are which also depends on the peoples' ability to read and write. Inability to research and get facts for themselves, make the people susceptible to the deceit of political office seekers. Whatever is said to them becomes the norm, making them to be unable to make truly free and independent political decisions. Inability to read and write equally makes the people politically ignorant and thus unable to know and exercise their political rights. Most African electorates do not know the extent and limit of their political rights. They do not know when to act and when to fail to act. They do not know when to speak and when to refrain from speaking. They do not know when to revolt and when to cheer.

The political ignorance of majority of Africans, make it possible for the political elites to exploit and manipulate them to fit into their selfish political goals and ambitions. Apart from illiteracy, which is absence of formal education, political socialization and consciousness remained necessary thematic factors to be dealt with. If the people are fully conscientized, market women, traders and other people in unskilled vocations, it will go a long way in redirecting political equation and democratic leadership of the Nigerian state will further be strengthened. Political education and socialization did not necessarily imply educational competence or qualifications, some countries that witnessed rapid positive political change did not necessarily have the best brains in the area of education. What was fundamental remained political consciousness, socialization and appetite to effect a positive change by initiating appropriate and people oriented policies. To buttress this, Anthony Gidden (2006) opines:

British don't much esteem intellectuals. During the course of my career, I have met politicians from many different countries. Britain is one of the few countries I have come across where there is virtually no direct transfer between universities and politics. There are some MPs who begin as university lecturers, but after that they become professional politicians and lose their connection to the academy. I know of no case where someone who is a full time professor in university has moved across into a prominent position in the commons. And the commons is quite openly anti-intellectual....Thursday 23, Nov, 2006 .

In most African states, it is selection that is the norm and not election. The votes of the electorates do not count. There is lack of transparency and accountability. The judiciary and the media are not truly free. Other principles of true democracy are either absent or ineffective and yet the masses are silent about it. This is exactly what illiteracy and political ignorance breed. Adequate political socialization and conscientization will certainly reduce if not eliminate these inordinate practices in the polity.

\section{Poverty}

Poverty is another major challenge to democracy in Africa. A person deprived of the basic wherewithal cannot effectively function politically. Over 70 per cent of Africans are believed to live below poverty line. This means more Africans are basically concerned with survival than in politics. Their over concern for survival makes them susceptible to manipulation by the rich politicians. That is exactly why it is common in Africa, to hear of buying of votes, especially in Nigeria. Due to ignorance and poverty, Africans are willing to sell 
their votes for as low as a cup of salt. Indeed, there is clear absence of integrity for a poor hungry person to preserve. This perhaps explains the reason for vote buying, bullying, ballot snatching, maiming and killing that characterize the electoral processes in Nigeria and other developing African countries.

Also, due to the cost of politics, only the rich can actually contest for elective positions. This means that, no matter how credible a person may be, he/she cannot exercise effectively his/her rights to be voted for because of poverty. This has made power to circulate only around a few rich powerful individuals, turning democracy in Africa to the left aristocratic bent.

Aside from individual poverty, national poverty is also a great hindrance to the effective take-off of democracy in Africa. African countries are among the poorest countries in the world. Democracy is not meant for poor countries because it is an expensive form of government. This will be made vivid, when we consider the billions spent on elections periodically, the billions spent on the salaries and allowances of the federal and state houses of representatives, billions spent on electoral tribunal cases. These monies will be enough to improve infrastructure and reduce the poverty and thereby elevating the living standard of the people. By indulging in democracy, Africa only succeeded in enmeshing itself deeper into poverty. The poverty of the citizens is deepened in the process, thereby increasing the failures of democracy. In an atmosphere of political culture, socialization and conscientization credible leaders if emerged will enthrone a culture of quality leadership, consistency of quality democratic policies and programme thereby avoiding periodic elections. Hence performing leaders need not be reelected as they remain in office until they become unfit for the job. Leadership is necessarily service to the people and not a theatre for conversion of commonwealth to private estates. Serving the people creditably and in line with the appropriate laws of the land will lay credence to the Lockean perception of sovereign power lying in the hands of the people. A performing leader continues to be in office until the people objectively discover that the leader now leads contrary to the enabling law and to the good of the people.

\section{COMMUNAL CONSCIOUSNESS}

One major factor militating against the growth of democracy in Africa is communalism. African communities which were basically communalistic where forcefully amalgamated to form countries. While the communal spirit kept the traditional communities united and alive, it has become a spoke in the wheel of progress for the amalgamated countries. Communalism or community-centeredness by nature drags individual into impenetrable clusters. Communalism demands that individuals of a certain community, draws towards the community and pursue its interest over and above the interest of others. The community is expected to be first and the individual second. This system worked well before amalgamation, when the communities where autonomous and independent, but now that these communities are expected to accommodate and embrace others as one, it has become a big challenge. This tendency to cling to one's community has bred what is variously referred to as tribalism or ethnocentrism.

The demand of the communal spirit that everybody seeks to foster the interest of his/her immediate community has been the bane of democracy in Africa. Everybody now tends to cling to a political candidate from his/her community or ethnic group, irrespective of whether or not he/she is the most qualified candidate for the position. In turn, a political office holder tends to tilt more towards his/her community or ethnic group than others. As a consequence of this, democracy in Africa has tended to follow ethnic and tribal lines, contributing to its failure and numerous agitations from different ethnic groups. This phenomenon has aggressively metamorphosed into ethnic associations, terrorist and not-so terrorist group such as Independent 
People of Biafra (IPOB), Boko Haram, Fulani Herdsmen, Reformed Niger Delta Avengers (RNDA), Odua Peoples' Congress (OPC),

Democracy by its nature favours the domination of the minority by the majority. In a continent dominated by ethnic groups which are closed up to other ethnic groups, democracy will necessary pitch one ethnic group against the other in a struggle for supremacy. This is typified in Nigeria. Nigeria has been more divided in this democracy than it has ever been in the military regimes. There has never been a time in the history of Nigeria, that Nigeria has witnessed such division and infighting. One may point at the civil war. But the civil war was as a result of a friction between two groups. Today we have many groups agitating for freedom; the Niger Deltans agitating for independence, the Boko Haram seeking an Islamic state, the IPOB seeking a republic of Biafra, and Odua Peoples' Congress of Yoruba crying against marginalization. A lot of reasons have been blamed for these skirmishes. We blame the system of government in place. Democracy cannot help Nigeria or any African countries at the moment, it only tears the already fragile but healing wounds inflicted by a forceful unification of disparate groups into a country by their colonizers.

By making the various ethnic groups to compete for power and supremacy in elections, it puts a knife to the fragile bond that has been developing over time amongst the ethnic groups. This bond seems to have dissipated in Nigeria, placing the country at the verge of a total breakup - a breakup that may not be in two pieces but in many pieces. This breakup is not just about Nigeria, other African countries will be caught up with it too. However, this could be averted, if certain conditions are met.

\section{CONDITIONS FOR THE POSSIBILITY OF DEMOCRACY IN AFRICA}

To advise Africa against democracy now will be dysfunctional. Africa is already neckdeep in democracy and thus the only possible way to salvage it from its excruciating effects, is to fashion a kind of democracy that will fit African social, economic and political environment. The following measures to be considered:

Majority of the elective positions in the wisdom of this paper need to be made apolitical as much as possible. Elective positions in the federal and state houses of representatives/assembly, governors, local government chairmen and councillors should no longer be electorally contested. These positions should be filled like other positions in the ministries are. The positions of House of Representatives should be advertised like other job positions. Interview and selection should then be carried out and the selected people made staff of the federal or state government as the case may be, and their salaries fixed according to the national scale. State governors should be selected from the highest ranking staff of the state, the same way a vice chancellor is selected from the highest ranking staff of the university. Local government chairmen and councillors should also be selected by basis of ranks of staff of Local Government Councils. The highest ranking officer of the local government staff should be made the chairman and staff of a certain level and qualifications made the councillors of wards. It is only the presidential position that should be contestable. Doing this will eliminate the expenses incurred on these political positions, through huge salaries, allowances and more seriously the cost of running elections. It will also lead to rest, the ethnic sentiments that is now a mark of Africa. The billions spent on periodic elections, when put into other uses is capable of improving economic and infrastructural growth in the different countries of Africa. The trillions spent on political officers annually could create more job opportunities for Africans. The monies spent on campaign by political office seekers could be spent on other functional projects that would benefit everybody, instead of creating liabilities that the officers would want to recover 
while in government. This model is akin to the pat-time legislative model advocated by Ikegbu and Duru (2013).

The beauty of any democracy is based on the moral credentials of its legislature which will consequently reflect on the quality of laws and policies initiated and passed by them. Sadly, African political jurisdiction has the misfortune of having a legislature that think less of the happiness of their various constituents as a people.... a part time legislative arrangement can if put in use address some of the problems already faced in the legislative arm of government which consequently, affect the output of governance (p.56).

There is need for political education to make the people politically enlightened. True democracy revolves round the people, and the extent of citizen's involvement to a large extent is dependent on their political knowhow. Political education is therefore, necessary in Africa as the Sophists of ancient Athens discovered. The sophists took upon their shoulders the task of educating the citizens, in order that they may excel in the art of politics. Education in Africa should not be without this sophistic intent. Both the rulers and the ruled, must be trained to take up and perform their various duties well. Falaiye (2012) seemingly holds this position, considering his assertion: "I am convinced that good leaders are not born, but made. Training is very essential for those aspiring to become leaders at all levels ... ruling is a skill, just like any other skill, it requires training or tutelage to master" (p. 39). This point was also emphasized by Plato the ancient Greek philosopher, who held that the three classes of the society (the rulers, soldiers and workers) need to be educated, to enable them perform their duties well (Ikegbu \& Diana-Abasi 2017). Political office seekers if well-educated will understand that virtue and politics can co-exist; that rhetoric is a better tool to win elections than violence and ethnic incitement. Presently in Africa, politics is seen as a dirty game, making many honest people to disassociate from it. Proper education will put this belief in proper perspective. A careful survey will show that strong and stable democracies are only found in countries given to education. No country with poor educational system could sustain its democracy for long. Education imbues the citizens with the ability to read and write, thereby enabling them to communicate and work collaboratively with others. The colonial masters knew this fact well. They undertook the education of Africans, not really for the sake of love, but to make them capable of being ruled. To rule very well, one must make the followers able to be ruled. Democracy being a government of the people by the people cannot actually succeed if the people are ignorant. An ignorant populace cannot actually rule itself. This is why only the enlightened few rule in Africa, meaning that democracy in Africa is not government by the people but by a few. One good way to improve educational quality in Africa is to privatize the universities. The money spent on universities, could be channelled to the primary and secondary education, with the view of increasing quality of education at these levels. When the quality of education at the primary and secondary levels (which should be free) is improved, a graduate from these could meaningfully find his/her place in the society. Tertiary education is for specialization, and whoever desires that, should fund it himself/herself. The truth is that African nations are not rich enough to fund quality education at the moment. They should therefore, be no pretence about it.

Government should be decentralized. The powers of the federal government need to be diffused to the different states. Each state should be allowed to operate autonomously. States should control their resources and finances and a certain percentage sent to the federal purse. Overdependence on the federal government has made most states lazy and less creative. It is the federal government that ought to depend on the states and not the other way round. Selfdependence will make each state to think deeper in order to raise enough to keep itself afloat. These deep thinking will definitely lead to the creation of more jobs and consequently more wealth for the countries. Poverty is so widespread in Africa, especially in Nigeria, because the various states fold their hands and wait for allocation from the federal government. This 
allocation needs to stop, to enable the states to look inward with a view of developing what it has within.

\section{CONCLUSION}

A country that neglects education does so at its own peril. Education is so fundamental to a country, that it can never know development economically, socially, technologically and politically without a sound education (Ikegbu \& Bassey 2018; Ikegbu \& Bassey 2019). Nigeria and most other African countries lack this, which is why their political system is nose-diving. Most so called educated Africans are uneducated in political matters. Being educated in the university is not a guarantee that one is vested with the rubric of politics. There is need for curriculum review that will make civic education compulsory at all levels of education. Falaiye (1996) named courses he would want to be taught the would-be leaders in the country to include: Principles of justice, Ethics, the history of great world leaders, economic theories, truth telling, the art of public speaking, corruption, physical training (p. 252). To this list, this paper adds Rhetoric, geography, law, history of Nigeria/Africa, African values system and culture.

It is the firm assumption of this paper that studies of these will better equip Nigerians and all Africans to perform creditably their specific political duties. This together with operating a less expensive democracy will put Africa on the roadmap to greatness. It will make the dividends of democracy to begin to flow. Africa urgently needs to reconstruct democracy to fit its peculiar circumstances - performance base leadership will certainly reduce if not eliminate serial killings of Nigerian citizens in the name of political campaign. This will guarantee confidence on both the electorates and the elected or leaders.

\section{REFERENCES}

Appadorai, A. (1975). The substance of politics. Oxford: Oxford university press

Azikiwe, N. (1974). Renaissance Africa. London: Penguin Bks.

Coppleston, F. (1985). A history of philosophy. New York: Image press.

Dahl, R. (1964). Modern political analysis. Engle wood Cliffs, new jersey prentice hall.

Elijah, John. 2009. Man and the state: Issues in socio-political philosophy. Uyo: Afahaide \& brothers publishing co.

Elijah, John.2006. Man and knowledge: Issues in contemporary philosophy. Uyo: Scholars Press.

Falaiye, O. A. (1996). Neo-African socialism: A response to the fallacies in African socialism: PhD Thesis, University of Lagos.

Falaiye, O. A. (2012). "A philosopher interrogates African polis: How can we get it right?" presented at the university of Lagos inaugural lecture series.

Gidden, A. (2006). "Politically Illiterate Britain". The guardian newspaper, 23 November, 2006. www.theguardian.com

Ikegbu E. A (2012). "The place of Women in Political Development". Nigeria: Citizenship Education $2^{\text {nd }}$ Edition. Ozumba, G.O., Felix OnangEteng Mike Okom (eds). Aba: Vitalis Books.

Ikegbu E. A., \& Duru, S. A. (2013) "Nigerian Legislators and self esteem: A case for part time legislature". Journal of integrative humanism, Ghana, 3(1), 101-19.

Ikegbu, E. A., \& Bassey, S. A. (2018). Globalization from WHO and for Who: A Tour to Reformed Imperialism. 


\section{Predestinasi}

Vol. 13, No. 2, Desember 2020, Hal. 107- 114

Ikegbu, E. A., \& Bassey, S. A. (2019). Ahamefula: discovering leadership gaps of the African being. Multidisciplinary Research Journal, 75.

Ikegbu, E. A., \& Diana-Abasi, F. I. (2017). Utilitarianism as a Veritable Vehicle for the Promotion of a Just Society. Lwati: A Journal of Contemporary Research, 14(2), 121137.

Ikegbu, E. A., \& Enyimba, M. (2010). Unity and National Development in Nigeria. African Journal of Religion, Culture and Society, 2(2), 119-126.

Ikegbu, E. A., Duru, S. A., \& Ndem, S. (2013). African Socialism: Metaphor for Political Freedom and Economic Prosperity. Journal of Integrative Humanism, 3(1), 37-50.

Lawrence, A. (2011). Challenges of democracy. http://www.goggle search.com. Retrieved on September .

Wilson, N. G. (2006). Encyclopedia of ancient Greece. New York: Routledge. 